\title{
BEST PRACTICES FOR DEMAND-DRIVEN SUPPLY CHAIN MANAGEMENT IN PUBLIC HEALTHCARE SECTOR: A SYSTEMATIC LITERATURE REVIEW
}

\author{
M. Bvuchete ${ }^{1 \#}$, S.S. Grobbelaar ${ }^{1,2 *}$ \& J. van Eeden ${ }^{1}$
}

\section{ARTICLE INFO}

\section{Article details}

Submitted by authors 14 Jun 2018 Accepted for publication 17 Jun 2020 Available online $\quad 31$ Aug 2020

\section{Contact details}

Corresponding author ssgrobbelaar@sun.ac.za

Author affiliations

1 Department of Industrial Engineering, Stellenbosch University, South Africa

2 DST-NRF Centre of Excellence in Scientometrics and Science, Technology and Innovation Policy (SciSTIP), Stellenbosch University, South Africa

\# Author was enrolled for a PhD in the Department of Industrial Engineering, Stellenbosch University, South Africa

\section{DOI}

http://dx.doi.org/10.7166/31-2-2006

\section{ABSTRACT}

Healthcare supply chains ensure that there is a cost-effective availability of medicines at healthcare facilities. However, it appears that public healthcare supply chains in South Africa are experiencing significant challenges in the management and distribution of the right medicines, at the right time, and at the right cost. This has resulted in poor healthcare outcomes. Moreover, public health supply chains also face major challenges due to rising patient expectations and inefficiencies in supply chain operations. There is recent interest in increasing public health supply chain efficiency and improving patient services. To address these challenges and opportunities, other studies have suggested the transformation of healthcare supply chains from the current pure 'push' approach into a 'pull' approach, which is driven by actual customer demand (demand-driven supply chain management DDSCM). However, no guidelines exist to support the design of DDSCM in public healthcare supply chains. Therefore, through a systematic literature review, this study aims to distinguish the key success factors for the DDSCM approach from those of other industries, and subsequently develops a framework to guide the design of DDSCM for the public healthcare sector.

\section{OPSOMMING}

Voorsieningskettings vir gesondheidsorg verseker dat medisyne kostedoeltreffend by gesondheidsorgfasiliteite beskikbaar is. Dit wil egter voorkom asof openbare voorsieningskettings vir openbare gesondheidsorg in Suid-Afrika aansienlike uitdagings ondervind met die bestuur en verspreiding van die regte medisyne, op die regte tyd en teen die regte koste. Dit het gelei tot swak gesondheidsuitkomste. Boonop staar die verskaffingskettings vir openbare gesondheid ook groot uitdagings in die gesig weens toenemende verwagtinge van die pasiënt en ondoeltreffendheid in die verskaffingskettingbedrywighede. Daar is onlangs belangstelling in die verhoging van die doeltreffendheid van die verskaffingsketting van openbare gesondheid en verbeterde pasiëntdienste. Om hierdie uitdagings en geleenthede aan te spreek, het ander studies voorgestel dat die verskaffingsketting van gesondheidsorg vanaf die huidige 'pure push'-benadering na 'n trekbenadering oorgedra word, wat deur die werklike vraag van die kliënt gedryf word ('demanddriven supply chain management' [DDSCM]). Daar bestaan egter geen riglyne om die ontwerp van DDSCM in verskaffingskettings vir openbare gesondheidsorg te ondersteun nie. Daarom, met behulp van 'n sistematiese literatuuroorsig, is hierdie studie ten doel om die belangrikste suksesfaktore vir die DDSCM-benadering van ander bedrywe te identifiseer, en word daarna 'n raamwerk ontwikkel om die ontwerp van DDSCM vir die openbare gesondheidsorgsektor te lei.

\section{INTRODUCTION AND PROBLEM STATEMENT}

The gross domestic product (GDP) expenditure on healthcare in South Africa equates to almost 8.5 per cent of GDP, as shown in Figure 1. Despite such high expenditure on healthcare, South Africa is still experiencing 
poor healthcare outcomes - such as high infant mortality and low life expectancy - when compared with other middle-income countries [1], [2].

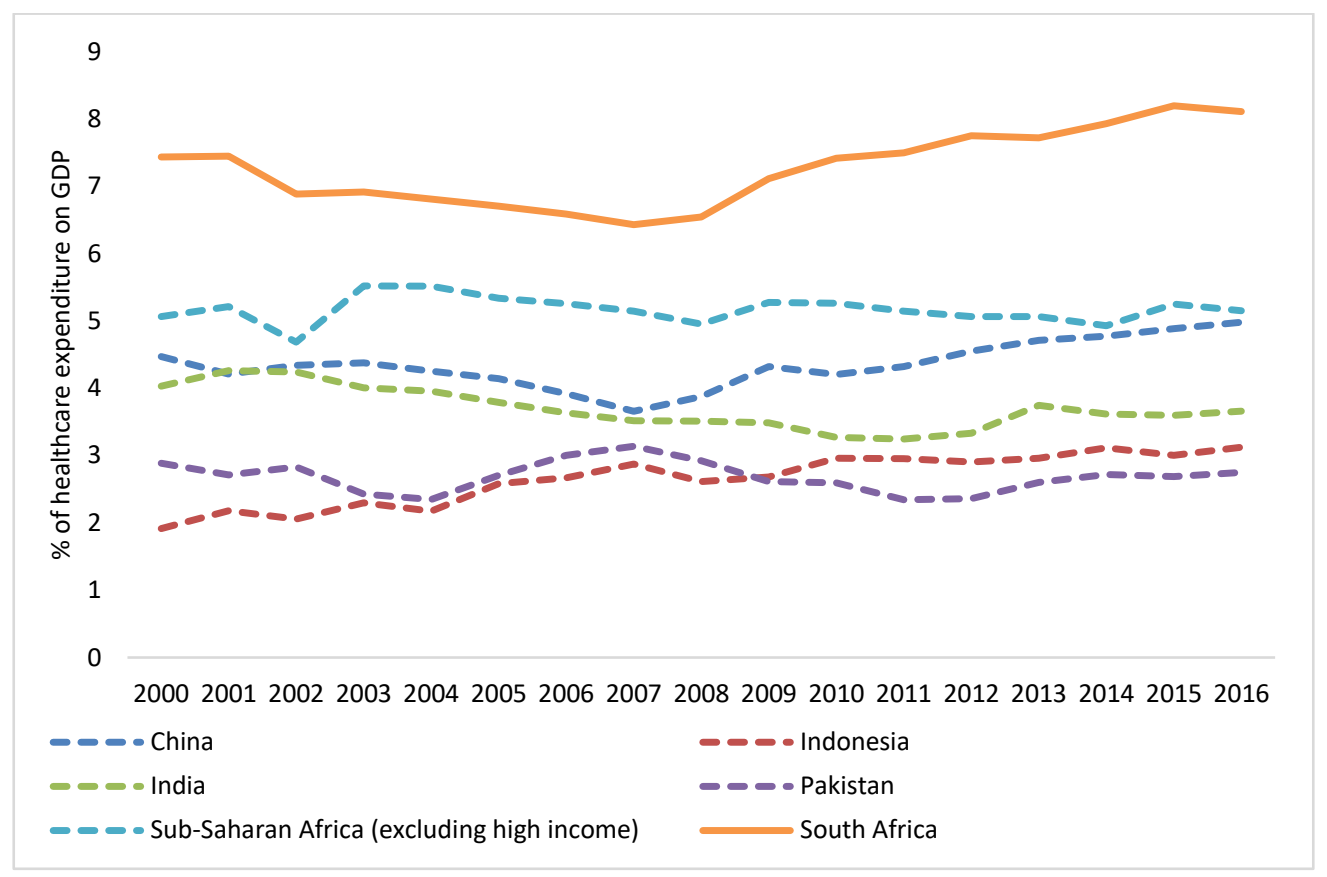

Figure 1: Indicators for middle-income economies (2000-2016) [1]

South Africa is still burdened by a high human immunodeficiency virus (HIV) prevalence $(13.06 \%$ in 2018$)$ and a high incidence of cases of active TB (567 cases of active tubercle bacillus (TB) per 100000 people in 2017). This means that stock-outs of medicines will have severe impacts on these affected populations. Medicine stock-outs thus increase the risk of the emergence of drug-resistant strains in the health delivery system, and also result in high levels of morbidity and mortality [3]. The need to develop agile and efficient healthcare supply chain systems is thus important [4].

\subsection{Healthcare supply chain}

A healthcare supply chain is an ecosystem consisting of a combination of organisations, people, technology, activities, information and resources that facilitate the delivery of healthcare products, vaccines, and other medicines from the manufacturer to the end-patient in a cost-effective way [5]. The prime purpose of public healthcare supply chains is to ensure agile healthcare delivery systems to the citizens of a country, regardless of their geographic location, and in response to diversified patient needs [6]. A strong healthcare delivery system cannot function without a well-designed, well-operated, and well-maintained supply chain management (SCM) system - one that can ensure an adequate supply of essential healthcare products to the patients who need them [7]. However, public healthcare supply chains are not only growing in size, they are also becoming more complex with the increasing number of interconnected parts and feedback loops within the system [8]. Furthermore, public health supply chains face major challenges due to rising patient expectations and inefficiencies in supply chain operations. This has sparked interest in increasing public health supply chain efficiency and improving patient services [6].

With low forecast accuracy and high demand variability, organisations in supply chain networks usually have to increase safety stock levels, or expeditiously move products from one location to another. However, these initiatives hurt operational efficiency and increase supply chain costs. To cope with this scenario, many organisations are trying to move from a pure 'push' strategy, which is only driven by forecast, to a 'pull' strategy, which is driven by actual customer demand. This system ensures a better balance between supply and customer demand, thereby delivering expected customer service levels and supply chain efficiency [9]. Current management systems and practices in public healthcare supply chains are less and less able to cope with the growing complexities of low forecast accuracy and demand variability, which results in medicine stock-outs, poor healthcare outcomes, high supply chain costs, and operational inefficiencies [8]. Other studies in the literature, however, support this notion of a pull-based supply chain strategy, and suggest that healthcare supply chains need to move towards an integrated 'demand pull' 
model (demand-driven supply chain management [DDSCM]) that enables medicine manufacturers to monitor the actual consumption of medicines [10].

Although this pull system has been established in industries such as computers, fruit, flower, telecommunications, transport, beef, and fashion [11]-[13] to manage supply chain complexity, demand volatility, and uncertainty [9], previous work has not comprehensively considered this system in the public healthcare sector. The focus that is required is to ensure that supply chains are engineered to match demand requirements [14] in the public healthcare sector. However, no frameworks exist to support the implementation of DDSCM in the public healthcare sector. This becomes a challenge for organisations that want to adopt DDSCM practices in the public healthcare sector.

Therefore, the research questions for this study are:

- What key success factors for DDSCM that are used in other industries can be adopted for the public healthcare sector?

- What does a framework that supports the design of DDSCM for the public healthcare sector look like?

\section{THEORETICAL BACKGROUND OF DEMAND-DRIVEN SUPPLY CHAIN MANAGEMENT}

The DDSCM concept was originally adapted by manufacturing companies as a pull production system, but it can apply equally to supply chains. The first classic pull system was called a two-card 'kanban' system that was pioneered by Toyota [15]. The kanban system implies that production on a workstation starts only when the succeeding station or customer has requested or 'pulled' parts, and not before. In a manufacturing context, a production pull system involves the amount of work in progress being explicitly limited, as opposed to a push production system, which does not limit the amount of work in progress. Pull systems can be classified as strategic, where customers dictate the pace of production, or as tactical, where the amount of work in progress is explicitly limited by demand [15]. Hull [16] likened push and pull systems to the make-to-stock and make-to-order philosophies respectively. Therefore demand-driven production is conceptualised as the synchronised execution of compliant production and logistics processes across a supply network to satisfy customer demand [17].

One of the characteristics of a pull-based approach is the flow of timely and relevant information [18]. This results in improved supply chain efficiency [19]. Note also that the key in demand chain management (DCM) is the continuous flow of the demand information from customers to all supply chain partners. In essence, DCM is a demand-driven process based on the pull approach. DDSCM consists of coordinated technologies and processes that collect, analyse, and share real-time demand and inventory information across all supply chain partners [20]. It is suggested that the combination of the demand and the supply concepts gives rise to a DDSCM, which is fundamentally a pull system [9]. The same idea is described by Barret [17], who defined a demand-driven supply network (DDSN) as a system of processes, technologies, and organisation that captures and responds to signals across a network. O'Marah [21] further suggests that DDSN is not another name for SCM; it is an approach that addresses organisational areas that were being overlooked by classic SCM, and that promises huge growth and efficiencies.

Studies in DCM also explore the concept of DDSCM. DCM emphasises practices that seek to manage and coordinate the demand chain, beginning with the customer, and then moving backwards to the raw material suppliers [22]. By contrast, supply chain management (SCM) is more focused on 'pushing' products from manufacturers to customers (whereas in DCM products are pulled by customers from manufacturers) [23]. Canever, Trijp and Beers [11] argue that DCM evolved from SCM, and is much broader than SCM. Their argument is based on the fact that DCM's prime focus is on customer orientation and the design of the supply chain is based on customer needs. This implies matching supply with demand. However, other authors conceptualise the DCM concept as only a change of SCM nomenclature, and suggest that this change of nomenclature will cause confusion. But they also acknowledge the co-existence of a demand chain and a supply chain. The only difference is on the focus of each chain. Demand chains focus on market mediation, and supply chains focus on efficient physical supply [24]. Many DCM studies strongly emphasise customer demand as the core focus of DCM [9], [11], [19], [25]-[27]. DCM also involves the integration and alignment of demand and supply processes [25], [27]. 
A grounded theory-based approach was followed to develop the framework, using the conceptual framework analysis (CFA) process proposed by Jabareen [28]. CFA is a process comprising eight steps, as shown in Table 1. Data sources were mapped, and the concepts identified, deconstructed, and categorised. The concepts were then integrated and synthesised into a framework.

Table 1: Overview of CFA and its implementation

\begin{tabular}{|c|c|c|c|c|}
\hline Phase & CFA phases [28] & Objective of phase as per CFA & $\begin{array}{l}\text { Alignment with section in } \\
\text { this paper }\end{array}$ & Objectives of part \\
\hline 1 & $\begin{array}{l}\text { Mapping data } \\
\text { sources }\end{array}$ & $\begin{array}{l}\text { Map spectrum of } \\
\text { multidisciplinary literature }\end{array}$ & \multirow{4}{*}{$\begin{array}{l}\text { Part 1: } \\
\text { Investigation and } \\
\text { discovery of sources and } \\
\text { subsequent concept } \\
\text { identification and } \\
\text { categorisation (section 4) }\end{array}$} & \multirow{4}{*}{$\begin{array}{l}\text { Systematise the } \\
\text { literature review } \\
\text { Include investigation } \\
\text { of key success } \\
\text { factors of DDSCM } \\
\text { from other industries }\end{array}$} \\
\hline 2 & $\begin{array}{l}\text { Reading and } \\
\text { categorising data }\end{array}$ & $\begin{array}{l}\text { Read selected data and } \\
\text { categorise by discipline and } \\
\text { scale of importance }\end{array}$ & & \\
\hline 3 & $\begin{array}{l}\text { Identifying and } \\
\text { naming concepts }\end{array}$ & $\begin{array}{l}\text { Read and re-read data to } \\
\text { discover concepts, and allow } \\
\text { concepts to emerge from the } \\
\text { literature }\end{array}$ & & \\
\hline 4 & $\begin{array}{l}\text { Deconstructing } \\
\text { and categorising } \\
\text { concepts }\end{array}$ & $\begin{array}{l}\text { Identify the main attributes, } \\
\text { characteristics, assumptions, } \\
\text { and role of each concept. This } \\
\text { is followed by categorising the } \\
\text { concepts }\end{array}$ & & \\
\hline 5 & $\begin{array}{l}\text { Integrating } \\
\text { concepts }\end{array}$ & $\begin{array}{l}\text { Integrate and group together } \\
\text { similar concepts to form one } \\
\text { group of concepts }\end{array}$ & \multirow[t]{2}{*}{$\begin{array}{l}\text { Part 2: Development of } \\
\text { framework (process } \\
\text { described in section 5) }\end{array}$} & \multirow[t]{2}{*}{$\begin{array}{l}\text { Integrate and } \\
\text { synthesise findings } \\
\text { into a framework }\end{array}$} \\
\hline 6 & $\begin{array}{l}\text { Synthesis and } \\
\text { resynthesis }\end{array}$ & $\begin{array}{l}\text { Synthesise concepts into a } \\
\text { framework. This is an iterative } \\
\text { process, and includes repetitive } \\
\text { synthesis and resynthesis }\end{array}$ & & \\
\hline 7 & $\begin{array}{l}\text { Framework } \\
\text { evaluation }\end{array}$ & $\begin{array}{l}\text { Establish whether the } \\
\text { framework makes sense }\end{array}$ & \multirow[t]{2}{*}{$\begin{array}{l}\text { Part 3: (Future work) } \\
\text { Framework validation }\end{array}$} & \multirow{2}{*}{$\begin{array}{l}\text { Evaluate and modify } \\
\text { the framework in } \\
\text { three stages: } \\
\text { Semi-structured } \\
\text { interviews } \\
\text { Ranking interviews } \\
\text { Case studies } \\
\text { This is a continuous } \\
\text { process of evolving } \\
\text { the framework }\end{array}$} \\
\hline 8 & $\begin{array}{l}\text { Rethinking } \\
\text { framework }\end{array}$ & $\begin{array}{l}\text { A multidisciplinary framework } \\
\text { will always be dynamic, and } \\
\text { needs to be revised }\end{array}$ & & \\
\hline
\end{tabular}

A systematic literature review (SLR) was employed to select a representative sample of published articles on the DDSCM approach. This is because the SLR method is an evidence-based process that is intended explicitly to evaluate all published and unpublished literature. It is highly replicable [29] and transparent, and thus minimises bias [30]-[32]. The SLR process followed in this article is shown in Figure 2. Qualitative content analysis (QCA) was then applied to analyse the articles. QCA is both a qualitative and a quantitative approach, involving the systematic codification and analysis of textual data [33]. Another motivation for using an SLR is that it adheres to standardised methodologies to systematically search, filter, review, critique, interpret, synthesise, and report findings from multiple publications on a topic of interest.

\section{PART 1: INVESTIGATION AND DISCOVERY OF SOURCES AND SUBSEQUENT CONCEPT IDENTIFICATION}

\subsection{Data collection}

The search was restricted to scientific journals, conference proceedings, technical reports, and textbooks. Three data sources were searched: Scopus, Web of Science, and Science Direct. An initial search strategy with the key words ((demand driven) AND (supply chain) AND (Healthcare) OR (Pharmaceuticals) OR (Medicines)) was used. Only one article was retrieved. The researchers then decided to broaden the search strategy to include the key search terms shown in Table 2. 


Stage 1:
(Data collection)
Planning the review
a) Formulate your study question
b) Define criteria for reporting
study accessibility
c) Decide on the
inclusion/exclusion criteria
(PRISMA)

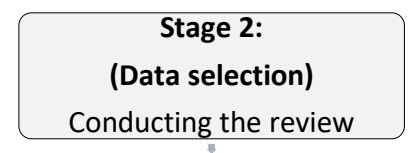

a) Identify concepts to be included in your search

b) Key words and search terms

c) Select databases relevant to your research

d) Snowballing

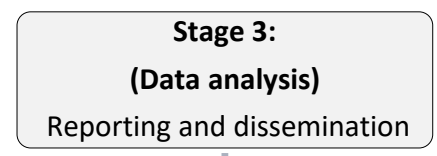

a) Identify main contributors to the main research

b) Identify where the contributors are based

c) Identify when the research was conducted by the contributors

Figure 2: Systematic literature review process

Table 2: Literature search criteria

\begin{tabular}{|l|l|l|l|l|}
\hline & Search terms & Scopus & $\begin{array}{l}\text { Web of } \\
\text { Science }\end{array}$ & $\begin{array}{l}\text { Science } \\
\text { Direct }\end{array}$ \\
\hline$\# 1$ & $\begin{array}{l}\text { ((demand driven) AND (supply chain) AND ((visibility) OR } \\
\text { (information sharing)) }\end{array}$ & 64 & 52 & 178 \\
\hline$\# 2$ & $\begin{array}{l}\text { ((customer driven) AND (supply chain) AND ((visibility) OR } \\
\text { (information sharing)) }\end{array}$ & 46 & 34 & 165 \\
\hline$\# 3$ & $\begin{array}{l}\text { ((pull) AND (supply chain) AND ((visibility) OR (information } \\
\text { sharing)) }\end{array}$ & 34 & 24 & 1169 \\
\hline
\end{tabular}

\subsection{Data selection}

The framework that is used for SLR to ensure methodological rigour and quality is called 'preferred reporting items for systematic reviews and meta-analysis' (PRISMA). This methodology addresses quality issues such as bias, replicability, and credibility. It offers a broader and more accurate level of understanding than a traditional literature review. Figure 3 describes the data section criteria using the PRISMA methodology. An initial search yielded 1000+ studies, of which 87 were topic-related. Even so, the selected sample is based on convenience, with 76 studies accessible. After reading the abstracts of these papers, only 35 studies were deemed relevant for the systematic literature review. A snowball strategy was used on the references of these studies, and eight more studies were added to make a final data set of 43 studies.

\subsection{Data analysis}

This section analyses the dataset of journals, conference papers, and reports that were collected from the three databases. The 43 studies that were included for review were classified into the type of journals, conferences, and reports (Appendix 1), classification by publication year of the studies, classification of the DDSCM studies by industry type, and classification of the studies by the methodology used.

\subsubsection{Classification of studies by year of publication}

Figure 4 shows the studies that discussed the DDSCM approach. Between 1998 and 2003 studies of demanddriven supply chain management were limited. The concept only gained recognition between 2003 and 2008, when the concept of demand chain management was introduced. In this period, other studies also discussed the pull supply chain approach from a production planning perspective. The number of studies started to drop in 2008, as shown by Figure 4. 


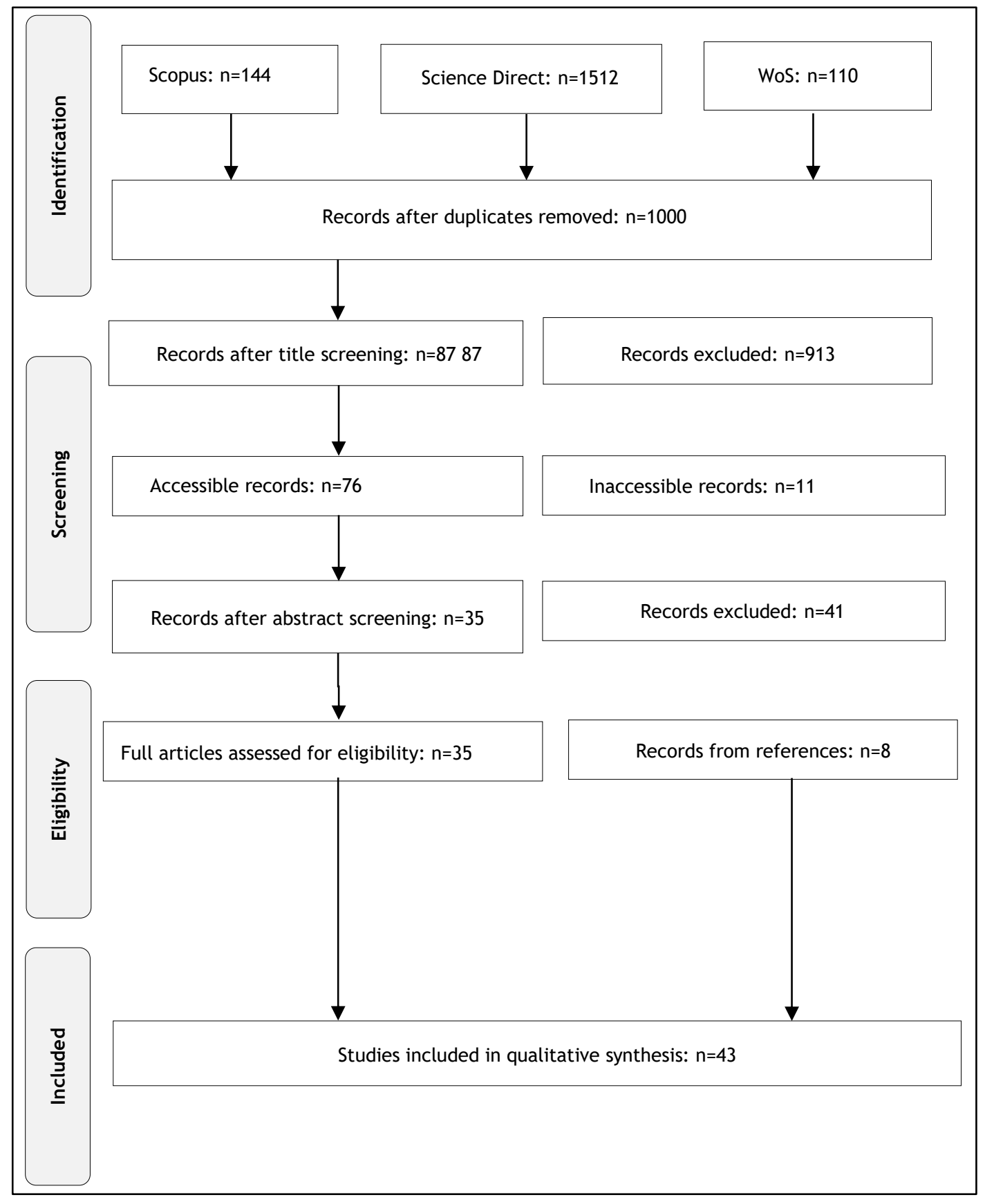

Figure 3: Preferred reporting items for systematic reviews and meta-analysis (PRISMA) 


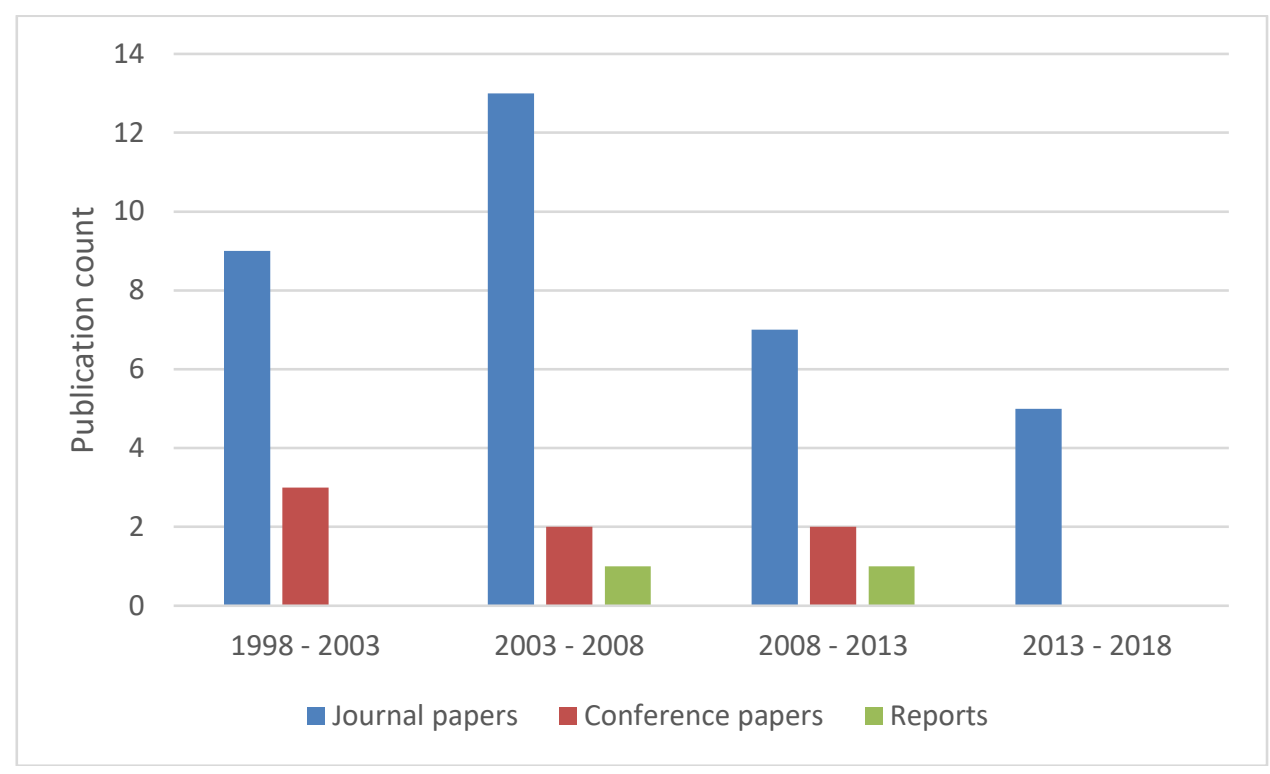

Figure 4: Classification of studies by years of publication

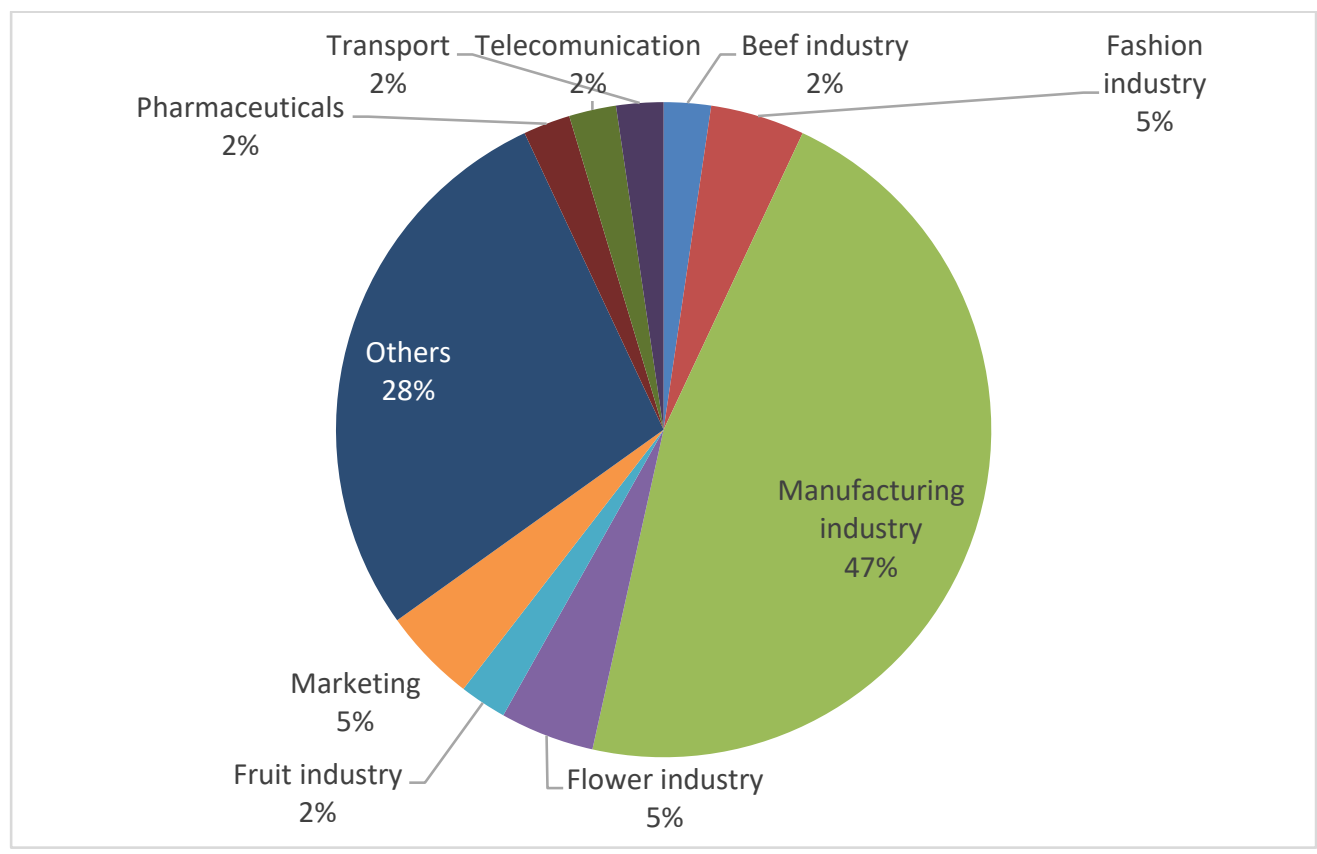

Figure 5: Classification of DDSCM studies by industry type

\subsubsection{Classification of DDSCM studies by type of industry}

The DDSCM studies found in the literature searched were categorised into nine sectors: manufacturing, beef industry, transport, fashion industry, flower industry, fruit industry, pharmaceuticals, marketing, and telecommunications. This is shown in Figure 5.

Some studies that did not specify the sector from which the studies were derived were classified as 'Other' in Figure 5. It is important to note that most studies on DDSCM are developed in the manufacturing sector, the fashion industry, the flower industry, and marketing. Two schools of thought from two different sectors that are worth mentioning are the manufacturing industry perspective and the marketing perspective. They both emphasise the customer as the start of the supply chain. The manufacturing industry postulates best manufacturing practices that enable an organisation to be responsive to customer needs, such as kanban, lean manufacturing, vendor-managed inventory (VMI), collaborative planning forecasting and replenishment (CPFR), and agile distribution [21]. The marketing sector argues that DDSCM in an 
organisation is a result of the integration of supply chain management and the marketing discipline [27]. These authors posit that supply chain management interfaces the supply side of the business, such as manufacturing and distribution, while marketing interfaces the downstream supply chain identifying customer needs.

\subsubsection{Classification by methodology}

Most studies on DDSCM are conceptual, and are only based on a literature review, with some papers also including case studies. Surveys and simulations are also used as research methods in the studies examined in the systematic literature review. Cross-sectional qualitative studies and interviews are also used as research methods. These are illustrated in Figure 6 . This highlights that the concept of DDSCM is still highly theoretical and lacks significant empirical validation through methods such as case studies and interviews, as shown in some of the studies under review.

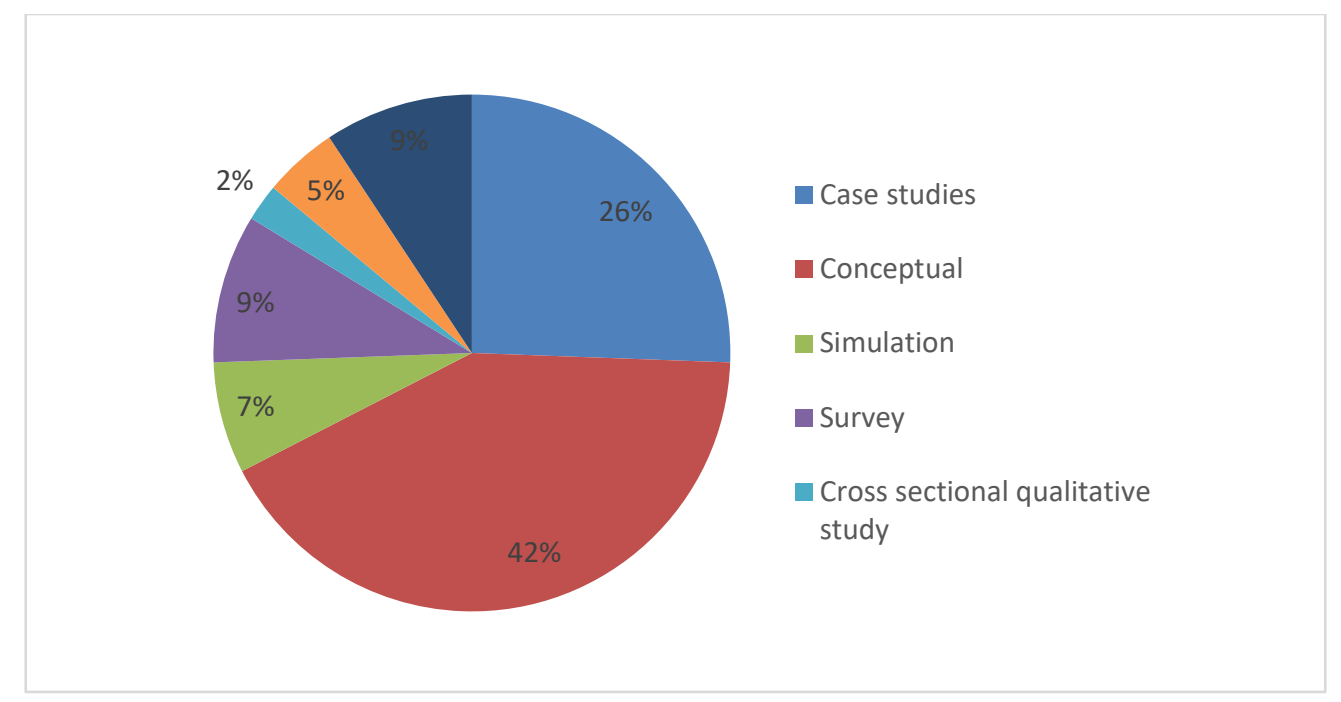

Figure 6: Classification based on methodology

\section{$5 \quad$ PART 2: DEMAND DRIVEN SUPPLY CHAIN MANAGEMENT FRAMEWORK DEVELOPMENT}

Through a systematic literature review, DDSCM concepts were identified, categorised, and synthesised into a framework. The seven key dimensions for DDSCM in the framework are visibility, technology, organisational alignment, collaboration, human resources, distribution management, and performance management. The key success factors (capabilities) outline actions and activities that need to be performed for organisations to become demand-driven. Moreover, supply chain stakeholders were outlined in the framework as entities or organisations that are involved in supply chains. Supply chain processes adopted from the supply chain operations reference (SCOR) model were also included in the framework. Last, the key supply chain flows, which include products, information, and finance, formed part of the integrated framework (Figure 7).

\subsection{Demand-driven supply chain dimensions and capabilities}

This section describes the core dimensions and their associated capabilities that enable the DDSCM concept, as shown in Figure 7.

\subsubsection{Organisational alignment}

Organisational alignment is a methodology that supports people and organisations through transitions. For the purposes of this study, organisational alignment in a demand-driven organisation involves the transformation process in which the organisational vision focuses on the 'outside-in strategy' [17]. The outside-in strategy has the customer as the starting point of the supply chain [22]. Therefore the first step is to understand the actual customer demand and then translate that demand into strategies and plans. The strategies include customer segmentation [19] and product classification [34]. Organisational alignment combines organisational vision, goals, culture, roles and responsibilities [17], cost management, customer segmentation [11] and product classification [35], senior management support [9], positioning of decoupling points, and demand strategy. The organisational metrics should also be aligned to supply the chain's goals and objectives [17]. 


\subsubsection{Distribution management}

Distribution management can be defined as an organisation's ability to facilitate the storage and flow of products in an attempt to satisfy customer demand in a reliable and efficient way [36]. Distribution management capabilities involve best practices such as warehouse and inventory management, crossdocking, distribution planning and transportation management, customer order management and order fulfillment, and demand and supply planning [36], [37]. Warehouse management commonly bundles practices related to efficient handling, storage, and picking of products and inventory [38]. In this sense, optimising warehouse management processes through resources, automation and technologies, and warehouse management systems (WMS) enhances responsiveness and flexibility, and reduces errors, costs, and inventory levels [36]. Moreover, in cross-docking, inbound trucks deliver products to the warehouse, and the products are quickly sorted and loaded to outbound trucks based on customer demand and routes without inventory being held in the warehouse [37]. The cross-docking distribution strategy is a lead-time reduction technique involving processes that marry products received in a facility from different suppliers or destinations with other products being distributed to the same onward destination. These goods are distributed at the earliest opportunity without going into long-term storage [39]. Cross-docking reduces delivery time and some material handling costs.

Distribution planning and transportation management involves the optimisation of delivery schedules and transport routes and transport bundling to capitalise on economies of scale, thus reducing transport costs without compromising customer service [36]. This is conceptualised as 'internal organisational optimisation' [23]. Distribution optimisation also encompasses the capitalisation of other channel members' resources, such as transport systems, to improve responsiveness [40]. This can be accomplished through sharing and aligning information, intelligence, and resources across the value chain through increased process visibility [23]. Moreover the capability order fulfilment can be defined as the percentage of orders that are delivered accurately and on time, and that meet customer demand [17]. This is one of the goals of DDSCM; an organisation should thus develop it capabilities to deliver perfect orders where and when they are needed. Last, distribution management covers demand and supply planning. Demand planning entails demand forecasting and defining customer priorities and product priorities. On the other hand, supply planning involves balancing supply and demand [36] by coordinating inventory in response to the demand plan [41].

\subsubsection{Collaboration}

Supply chain collaboration is a long-term partnership process in which stakeholders with common goals work closely together to achieve mutual benefits that organisations would not be able to achieve individually [42]. It involves activities related to the joint planning and execution of supply chain activities [43]. Supply chain collaboration can enhance customer satisfaction by reducing lead times, improving service levels, and decreasing costs [44]. It enables partners jointly to gain a better understanding of product demand, and this guides stakeholders in the implementation of more realistic programmes to satisfy that demand [45]. The success of demand-driven processes is based on the strength of the relationships among supply chain partners and the efficiency of the logistics processes [18]. Close relationships and partnerships among supply chain partners are key components of performance improvement [45]. Furthermore, a good relationship between the customer and the supplier contributes significantly to a reliable information flow across the supply chain [19]. Failing to collaborate would result in the distortion of information (the 'bullwhip' effect) as it flows through the supply chain, which in turn could lead to costly inefficiencies, excess inventories, slow response, and lost benefits [45]. Through relationships and partnerships, the moment a product leaves the shelf of a retailer, a notification is sent to the manufacturer who, in turn, replenishes the product [46]. Supply chain relationships also encompass the close working together of supply chain partners to plan and execute supply chain operations in meeting common goals, thus achieving more benefits than acting independently. This is achieved through specific investments, knowledge sharing, complementary assets, and effective governance mechanisms [42].

Barratt [47] defines collaboration as a process that occurs when two or more organisations share the responsibility to exchange information that enhances their performance. The information shared among supply chain partners can be about plans, forecasts, delivery schedules, strategic information, and procedures. This information should be relevant, timely, and accurate [42]. It is through partnerships that organisations can reduce response times by obtaining information to streamline order fulfilment. The collaboration process also involves the joint analysis of future demand and inventory status, leading to joint collaborative planning and joint decision-making. Notably, the joint collaboration planning actions influence the strength of the relationships and the use of inter-organisation information systems in a demand-driven supply chain [48]. This also requires that supply chain partners orchestrate decisions in supply chain planning and operations that optimise supply chain benefits. Joint planning is used to align 
supply chain plans and coordinate decisions on inventory replenishment, order placement, and order delivery. The level of synchronisation in the decision-making process is a key element in building and maintaining mutual partnerships [42]. Joint planning and decision synchronisation is further enabled by the integration of both the information flows and the product flows from a multi-organisational point of view [44]. Heikkila [19] identifies the attributes of trust (such as reliability, which entails that supply chain partners fulfil their obligations) and benevolence (which entails that partners are also interested in the other organisation's welfare and will not embark on unexpected actions that might disadvantage the other partner). Goor [43] further suggests that cooperation and coordination in a supply chain is never possible without commitment. Commitment enables the formation of relationships and partnerships and subsequent information flows in a supply chain. Collaboration in a supply chain is also rooted in the concept of mutuality. Mutuality involves the sharing of supply chain risks, costs, and benefits among the supply chain partners [47]. This is achieved by integrating information systems and aligning processes among supply chain partners. In this sense, supply chain partners work as though part of a single organisation [42].

The dimension of collaboration also captures coordination as a capability. Coordination among supply chain partners enables organisations to execute their operations effectively and efficiently [20]. This can be accomplished through the development of synergy along the entire supply chain, and the development of capabilities to meet dynamic customer needs [23]. Coordination also relates to the integration of information systems and decision support systems for the purposes of enhancing supply chain visibility [49]. It also relates to improving capabilities to match supply and demand [25]. Coordination also involves the integration of demand and supply processes between organisations through agreements among supply chain partners. The agreements can be on frequent small batch deliveries, long-term contracts with suppliers, and the adoption of technologies in transaction execution, such as order placement and order management [25]. The last capability captured by the collaboration dimension is resource sharing - the process of leveraging capabilities and assets with supply chain partners to facilitate the flow of products and information across the supply chain in an attempt to reduce uncertainty and transactional costs. Resources such as physical assets, and technology such as vendor-managed inventory (VMI) software, allow suppliers to assess stock-level data of customers, thereby facilitating necessary replenishment actions [50]. Financial and non-financial investments such as time, money, training, technology updates, and other resources are also recognised as playing a significant role in collaboration [42].

\subsubsection{Visibility}

The intersection between information sharing and information quality is interpreted as visibility [51]. Information sharing is an optimisation strategy aimed at improving supply chain coordination and integration [49], while information quality can be described using seven characteristics: relevance, timeliness, continuous flow, validity, accuracy, intelligibility, and usefulness [52]. This information can be about customer demand, supply, or inventory levels [17], and must be transparent across the whole network [20]. Visibility throughout the supply chain enables organisations to be responsive to changes in demand [53]. In this sense, real demand and inventory visibility, when coupled with continuous replenishment programmes, ensure that DDSCM becomes a reality [13]. This is a capability that enables organisations to be able to match demand and supply [54].

\subsubsection{Technology}

Technology enables the capturing, analysis, and distribution of seamless, real-time demand and inventory information [40]. A fast data-exchange platform can facilitate the exchange of data among supply chain partners. This is key to the implementation of DDSCM [20]. This fast data-exchange platform can be a shared information technology platform among supply chain partners [44]. The distributed and linked supply chain platform serves as an information and communication platform that enables the integration of operations and interactive planning across various geographical locations and organisational levels. The supply chain platform provides members with access to network-wide real-time information, enables visualisation of available information, secures interaction between advanced ICT-based decision support tools and human decision-making, and creates a coordinated and collaborative environment for planning and decision-making [43]. The integration of information systems and technology platforms makes it possible to build demand-driven supply chains, enhancing the link between the customer and the supply chain system that delivers the customer's requirements [39].

Technology also facilitates supply chain visibility, information integration, and transparency, thus enhancing demand-based decisions [52]. This can be accomplished with demand-driven control systems such as collaborative planning forecasting replenishment (CPFR) [55], VMI, quick (consumer) response, and efficient consumer response [56]. The VMI software receives inputs of inventory and demand information, and recommends the correct order amounts and delivery schedules to the distributor to meet the actual demand [50]. In this sense, information technology and logistics are essential in facilitating the functions 
of DDSCM [44]. Key requirements for a state-of-the-art demand-driven supply chain management information management solution can be summarised as [52]:

- $\quad$ Strategic direction and focus - Needs to be derived from organisational strategy and organisational process requirements.

- Integration - Key aspects of integration to be covered are organisational process integration, including customers and suppliers, end-to-end demand, and the integration of process-wise performance management.

- Information coverage and availability - Access to real-time demand information and distribution channel information, and sharing the demand information with all parties in the chain.

- $\quad$ Flexibility and adaptability - An IT solution that is able to adapt to changes in organisational processes and requirements.

- Information quality - Information management solution must be designed in such a way that the best information quality is achieved.

\subsubsection{Human resources}

This key success factor describes the required skills, expertise, experience, and capacity of supply chain staff to manage and coordinate the supply chain [57]. To enhance this capability, organisations need to invest in talent development through continuous training programmes that are certified by professional bodies. And since people are the drivers of innovation, mechanisms should be in place to capture the new ideas of supply chain staff and to move the ideas into action [52]. Last, since DDSCM is centred on the concept of 'sense and respond', information is a capability for the success of DDSCM. Information management culture and skills are thus crucial to the success of the DDSCM approach [23].

\subsubsection{Performance management}

As part of the DDSCM concept, performance indicators should be defined, because they are fundamental to monitoring operations and evaluating performance in the supply chain. Second, performance measurements should support analysis. This entails historical and current data being used to analyse data across multiple dimensions, revealing trends, problems, and so on. Third, performance indicators should have a management application, fostering communication among executives, managers, and staff [43]. Performance management entails the measurement of supply chain performance [58], and supply chain performance measurements require a consistent and comparable holistic hierarchy of indicators, based on agreed-upon strategies, performance targets, and priorities [59]. It is therefore important to set appropriate metrics and goals, since these help the organisation to evaluate its performance and guide improvement [60]. Through an ICT-based performance measurement system, it is easy to realise real-time measurements and enhance decision-making with a collaborative perspective [43]. Since all organisations in a demand chain are customer-centric, it is vital to align organisational performance metrics with value chain performance metrics [23]. The supply chain metrics adopted from the supply chain operations reference (SCOR) model (reliability, cost, responsiveness, and agility) [57], which measure and monitor the performance of supply chain processes, will be used to evaluate the DDSCM processes.

\subsection{Supply chain stakeholders}

Supply chain stakeholders are entities or units that play a part, or are involved, in a particular supply chain [58]. For the purpose of the proposed framework, supply chain stakeholders are classified into three types: manufacturers, distributors, and customers. In the context of healthcare supply chains, three major stakeholders make up the healthcare SCN: producers, service providers, and purchasers [61]. The producers consist of pharmaceutical companies, medical device manufacturers, manufacturers of capital equipment, and information system and surgical products companies, while the purchasers include group purchasing organisations and pharmaceutical wholesalers and distributors. The service providers include hospitals, clinics, physicians, and pharmacies [62]. The healthcare supply chain also extends to include players such as patients, the government, and insurance companies [63]. These stakeholders determine the supply chain processes that are put in place.

\subsection{Supply chain processes}

The SCOR model supply chain processes - plan, source, make, deliver, return, and enable - were adopted for our framework. The 'plan' process involves demand and supply planning, inventory planning, production capacity planning, and the aggregation of demand and supply plans [64]. It also encompasses the collection of information on available resources and requirements [65]. The 'source' process includes activities related to the procurement of goods to meet planned and actual demand [64]. It also includes activities such as generating purchase orders, accepting invoices from suppliers, delivery scheduling, receiving goods, and the verification and storage of goods [65]. The 'make' process describes the processes related to the 
conversion of materials into a finished state in order to meet planned or actual demand [64]. The 'deliver' process describes the process of fulfilling customer orders, demand management, warehouse management, and transport management [64]. It also includes scheduling order delivery and shipment plans [65]. The 'return' process deals with the identification of a need to return goods [65], and subsequently with decisionmaking about receiving returned goods; it also extends into post-delivery customer support [64], and addresses activities such as scheduling the goods to be returned and the receipt of returned goods. Last, but not least, the 'enable' process describes activities associated with performance management, contract management, managing regulatory compliance, risk management, data management, resource management, and facilities management [65].

\subsection{Supply chain flows}

A supply chain is made up of multiple organisations or entities that directly facilitate the flow of goods, services, information, and finances [66]. From this definition, four types of flows in the supply chain are recognised. This study focuses on three major flows: goods (products), information, and finances.

Finally, all the concepts were integrated and synthesised into the framework shown in Figure 7. The framework outlines key supply chain stakeholders, supply chain processes, DDSCM dimensions, DDSCM capabilities (key success factors), and key supply chain flows. The proposed framework can be used as a guide to the design, development, and implementation of DDSCM.

\section{CONCLUSION}

The purpose of this paper was to identify the key success factors or capabilities for DDSCM that have been adopted in other industries, and then to propose a framework that can be applied in public healthcare supply chains for the design and implementation of the DDSCM approach. Through a systematic literature review, the key success factors for DDSCM were identified and categorised into seven dimensions in the framework: visibility, technology, collaboration, organisational alignment, human resources, distribution management, and performance management.

It was observed from the systematic literature review that most of the research on DDSCM focuses on manufacturing, followed by marketing. Even after realising the need for healthcare supply chains to transition from the pure push strategy to a pull strategy, there is still a lack of research on DDSCM in the healthcare sector. This study suggests that the theoretical framework proposed in this paper can act as a foundation for a comprehensive understanding of key dimensions that could be adopted by the healthcare supply chain in its transition towards a pull strategy. A limitation of this study, as presented in this article, is that it lacks empirical validity. However, through the empirical evaluation of the framework in the healthcare sector, the framework can be refined and aligned to suit the specific needs of the healthcare industry. 


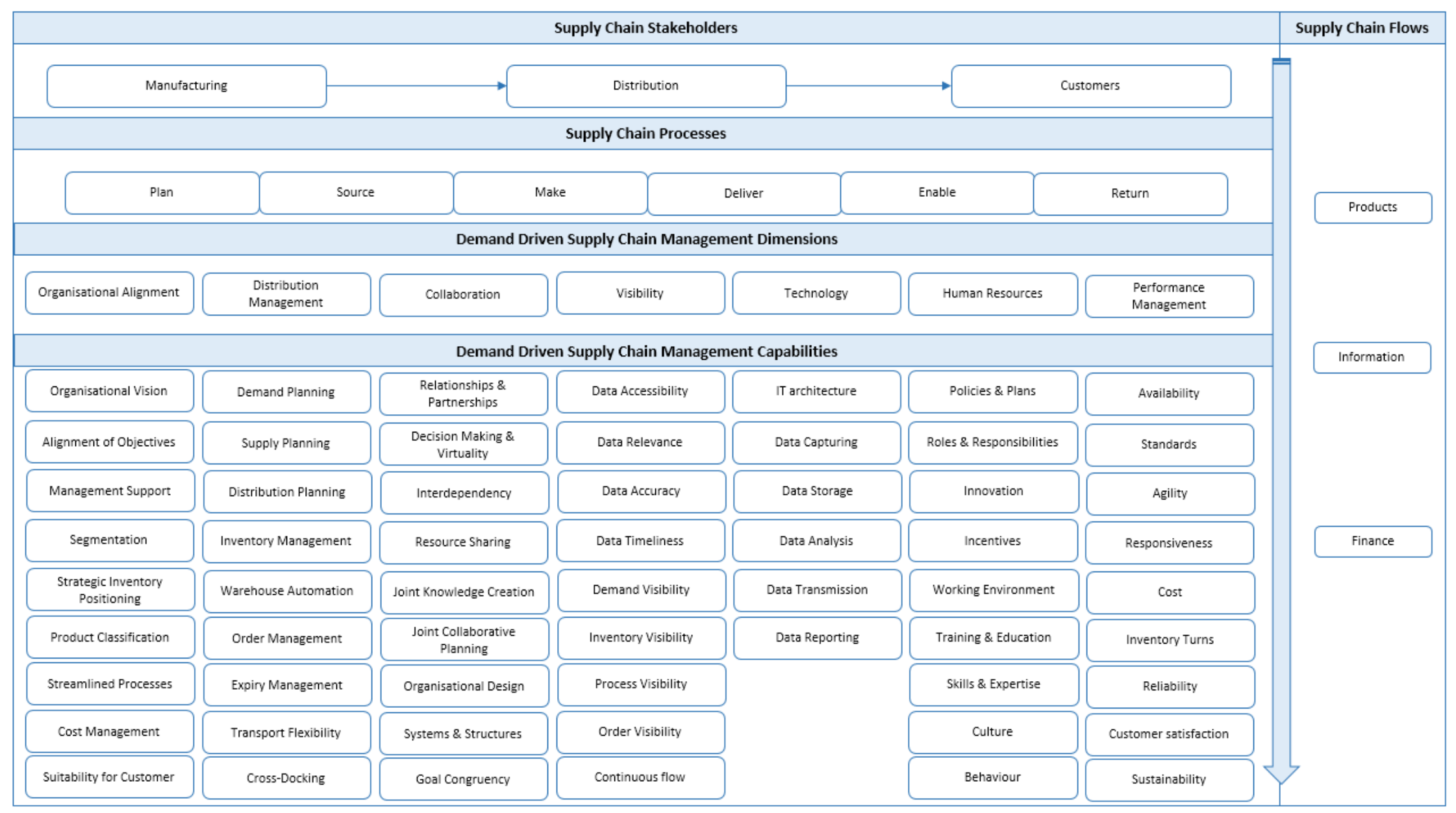

Figure 7: DDSCM framework 


\section{REFERENCES}

[1] Vargas Bustamante, A. and Shimoga, S. V. 2017. Comparing the income elasticity of health spending in middleincome and high-income countries: The role of financial protection. International Journal of Health Policy and Management, 7(3), pp. 255-263.

[2] Bidzha, L., Greyling, T. and Mahabir, J. 2017. Has South Africa's investment in public health care improved health outcomes? Working paper on Economic Research Africa. Pretoria, National Treasury of South Africa. Available at: https://econrsa.org/system/files/publications/working_papers/working_paper_663.pdf.

[3] Mokheseng, M., Horn, G. S. and Klopper, A. G. 2016. ScienceDirect supply chain solutions to improve the distribution of antiretroviral drugs (ARVs) to clinics in rural areas: A case study of the QwaQwa district. Health. SA Gesondheid, 22, pp. 93-104.

[4] Kokilam, M. B., Joshi, H. G. and Kamath, V. G. 2016. Strengthening the pharmaceutical supply chain management with information communication technology intervention: A windfall to the Indian rural public healthcare system. Journal of Health Management., 18(2), pp. 274-289.

[5] Yadav, P. 2015. Health product supply chains in developing countries: Diagnosis of the root causes of underperformance and an agenda for reform. Health Systems Reform, 1(2), pp. 142-154

[6] Serbout, M. A., Berrado, A. and Benabbou, L. 2016. Pharmaceutical products supply chain, in Logistics operations management (GOL), 3rd International Conference on IEEE, pp. 1-6.

[7] JSI. 2017. The supply chain manager' s handbook. Arlington, John Snow Inc.

[8] USAID. 2010. Reengineering Public Health Supply Chains for Improved Performance Guide for Applying Supply Chain Segmentation Framework', USA, USAID., pp. 1-50.

[9] Mendes, P., Leal, J. E. and Thome, A. M. T. 2016. A maturity model for demand-driven supply chains in the consumer product goods industry. International Journal of Production. Economics., 179, pp. 153-165.

[10] Byrnes, J. 2004. Fixing the healthcare supply chain. Boston: Harvard Business School.

[11] Canever, M. D., Van Trijp, H. C. M. and Beers, G. 2008. The emergent demand chain management: Key features and illustration from the beef business. Supply Chain Management. An International Journal, 13(2), pp. $104-115$.

[12] Caro, F. and Gallien, J. 2010. Inventory management of a fast-fashion retail network. Operations Research., 58(2), pp. 257-273.

[13] Christopher, M. and Towill, D. 2001. An integrated model for the design of agile supply chains. International Journal of Physical Distribution Logistics Management, 31(4), pp. 235-246.

[14] Childerhouse, P., Aitken, J. and Towill, D. R. 2002. Analysis and design of focused demand chains. Journal Operations Management., 20(6), pp. 675-689.

[15] Hopp, W. J. and Spearman, M. L. 2004. To pull or not to pull: What is the question? Manuf. Service Opertions Management, 6(2), pp. 133-148.

[16] Hull, B. Z. 2005. Are supply (driven) chains forgotten? Int. J. Logistics Management., 16(2), pp. 218-236.

[17] Barrett, J. 2007. Demand-Driven is an Operational Strategy', Industrial Management Management, 49(6), pp. 114.

[18] Ashayeri, J. and Kampstra, R. 2005. Demand Driven Distribution:The Logistical challenges and opportunities. Proceedings of International Trade and Logistics, Corporate Strategies and Global Economy. Le Havre: University of Le Havre, France.

[19] Heikkila, J. 2002. From supply to demand chain management efficiency and customer satisfaction. Journal Operations Management., 20, pp. 747-767.

[20] Budd, J., Knizek, C. and Tevelson, B. 2012. The Demand-Driven Supply Chain: Making it work and delivering results.' Boston, Boston Consulting Group.(online). Available at https: / /www.bcg.com/documents/file 106861.pdf. (accessed on 12 January 2017)

[21] O'Marah, K. 2005. It's all about the customer. Industrial Management, 47(2), pp. 1-8.

[22] Selen, W. and Soliman, F. 2002. Operations in today's demand chain management framework. Journal of Operations Management, 20, pp. 667-673.

[23] Seethamraju, R. 2014. Enterprise systems and demand chain management: A cross-sectional field study. Information Technology Management, 15(3), pp. 151-161.

[24] Treville, S., Shapiro, R. D. and Hameri, A. P. 2004. From supply chain to demand chain: The role of lead time reduction in improving demand chain performance. Journal of Operations Management., 21(6), pp. 613-627.

[25] Frohlich, M. T. and Westbrook, R. 2002. Demand chain management in manufacturing and services: Web-based integration, drivers and performance. Journal of Operations Management., 20(6), pp. 729-745.

[26] Bonomi, J. and Antone, S. D. 2014. Industrial marketing management reinventing the wheel ? A critical view of demand-chain management. Industrial Marketing Management., 43(6), pp. 1012-1025.

[27] Jüttner, U., Christopher, M. and Baker, S. 2007. Demand chain management: Integrating marketing and supply chain management. Industrial Marketing Management, 36(3), pp. 377-392.

[28] Jabareen, Y. 2009. Building a conceptual framework: Philosophy, definitions, and procedure. International. Journal of Quality Methods, 8(4), pp. 49-62.

[29] Bryman, Bell, Hirschsohn, Santos, D., DuToit, Masenge, Van Aardt and Wagner 2010. 'Research Methodology: Business and Management Contexts.' South Africa, Oxford University Press.

[30] Jackson, N. C. 2004. Background to Systematic Reviews', in Handbook - systematic review of health promotion and public health interventions. Cochrane, pp. 5-8.

[31] Kitchenham, B., Charters, S., Budgen, D., Brereton, P., Turner, M., Linkman, S. 2007. Guidelines for performing systematic literature reviews in software engineering: EBSE Technical Report. (Online). Available at: https: // www.elsevier.com /_data/promis_misc/525444 systematic reviews guide.pdf. Accessed on: 17 July 2017. 
[32] Petticrew, M. and Roberts, H. 2006. Systematic Reviews in the Social Sciences: A Practical Guide'. Washington, Blackwell Publishing.

[33] Santos, J. B. and D'Antone, S. 2014. Reinventing the wheel? A critical view of demand-chain management. Industrial Marketing Management., 43(6), pp. 1012-1025.

[34] Fisher, M. 1997. What is the right supply chain for your product? Harvard Business Review, 75(2), pp. 105-116.

[35] Payne, T. and Peters, M. J. 2004. What is the right supply chain for your products? International Journal Logistics. Management, 15(2), pp. 77-92.

[36] Rexhausen, D., Pibernik, R. and Kaiser, G. 2012. Customer-facing supply chain practices: The impact of demand and distribution management on supply chain success. Journal of Operations Management., 30(4), pp. $269-281$.

[37] Buijs, P., Vis, I. F. A. and Carlo, H. J. 2014. Synchronization in cross-docking networks: A research classification and framework. European Journal Operations Research, 239(3), pp. 593-608.

[38] Pillay, J. 2015. Development of a warehouse management maturity model framework for use by third party logistics service providers in south africa. Masters thesis, Stellenbosch University, Stellenbosch.

[39] Hines, T. 2004. Supply chain strategies: Customer-driven and customer-focused, 1st Edition. Oxford: Elsevier Butterworth-Heinemann.

[40] Agrawal, D. K. 2012. Demand chain management: Factors enhancing market responsiveness capabilities. Journal of Marketing Channels, 19(2), pp. 101-119.

[41] Llewellyn, E. 2016 National Strategy for Improved Availability and Access: Visibility and Analytics Network, pp. 112. Unpublished report.

[42] Cao, M., Vonderembse, M. A., Zhang, Q. Y. and Ragu-Nathan, T. S. 2010. Supply chain collaboration: Conceptualisation and instrument development. Int. J. Prod. Res., 48(22), pp. 6613-6635.

[43] Bjartnes, R., Strandhagen, J. O., Dreyer, H. and Solem, K. 2008 Intelligent and demand driven manufacturing network control concepts, Third World Conference on Production and Operations Management. JOMSA. Tokyo, Japan. pp. 1-15.

[44] Goor, A. R. Van 2001 Demand \& Supply Chain Management : A Logistical Challenge, in 17th International Logistics Congress, Thessaloniki, pp. 1-15.

[45] Sahay, B. S. 2003. Supply chain collaboration: The key to value creation. Work Study, 52(2/3), pp. 76-83.

[46] Lummus, R. R. and Vokurka, R. J. 1999. Managing the demand chain through managing the information flow: Capturing 'moments of information'. Production Inventory Management., 40(1), pp. 16-20.

[47] Barratt, M. 2004. Understanding the meaning of collaboration in the supply chain. Supply Chain Management. An International Journal., 9(1), pp. 30-42.

[48] Hadaya, P. and Cassivi, L. 2007. The role of joint collaboration planning actions in a demand-driven supply chain. Industrial Management Data Systems, 107(7), pp. 954-978.

[49] Mbhele, T. P. 2016. Decoupling paradigm of push-pull theory of oscillation in the FMCG industry. South African Journal of Business Management., 47(2), pp. 53-66.

[50] Haavik, S. 2000. Building a Demand driven, Vendor-Managed Supply Chain, Healthcare Financial Management, 54(2), pp. 56-61.

[51] Barratt, M. and Oke, A. 2007. Antecedents of supply chain visibility in retail supply chains: A resource-based theory perspective. Journal of Operations Management., 25(6), pp. 1217-1233.

[52] Korhonen, P., Huttunen, K. and Eloranta, E. 1998. Demand chain management in a global enterprise: Information management view. Production Planning Control, 9(6), pp. 526-531.

[53] Verdouw, C. N., Beulens, A. J. M., Trienekens, J. H. and Van Der Vorst, J. G. A. J. 2011. A framework for modelling business processes in demand-driven supply chains. Production Planning Control, 22(4), pp. 365-388.

[54] Frohlich, M. T. and Westbrook, R. 2002. Demand chain management in manufacturing and services: Web-based integration, drivers and performance, Journal of Operations Management, 20(6), pp. 729-745. doi: 10.1016/S02726963(02)00037-2.

[55] Fliedner, G. and Fliedner, G. 2007. CPFR: An emerging supply chain tool. Industrial Management and data systems, 103(1), pp.14-21. doi: 10.1108/02635570310456850.

[56] Caridi, M., Moretto, A., Perego, A. and Tumino, A. 2014. The benefits of supply chain visibility: A value assessment model, International Journal of Production Economics, 151, pp. 1-19. doi: 10.1016/j.ijpe.2013.12.025.

[57] APICS. 2017. SCOR framework. [Online]. Available: http://www.apics.org/apics-for-business/products-andservices/apics-scc-frameworks/scor. [Accessed: 28 August 2017].

[58] Du Toit, D. and Vlok, P. J. 2014. Supply chain management: A framework of understating. South African Journal of Industrial Engineering, 25(3), pp. 25-38.

[59] Dreyer, H. C., Strandhagen, J. O., Romsdal, A. and Hoff, A. 2010. Principles for real-time, integrated supply chain control: An example from distribution of pharmaceuticals. In IFIP Advances in Information and Communication Technology, 338, pp. 187-194.

[60] Croxton, K. L., Lambert, D. M., García-Dastugue, S. J. and Rogers, D. S. 2002. The demand management process. International Journal Logistics Management., 13(2), pp. 51-66.

[61] Narayana, S. A., Kumar Pati, R. and Vrat, P. 2014. Managerial research on the pharmaceutical supply chain: A critical review and some insights for future directions. Journal of Purchasing and Supply Management, 20(1), pp. 18-40.

[62] Burns, L.R., DeGraaff, R.A., Danzon, P.M., Kimberly, J.R., Kissick, W.L. and Pauly, M.V. 2002. 'The Wharton School study of the health care value chain.' The health care value chain: producers, purchasers and providers. San Francisco: Jossey-Bass, pp.3-26.

[63] Kritchanchai, D. 2012. A framework for healthcare supply chain improvement in Thailand. Operations Supply Chain Management, 5(2), pp. 103-113.

[64] Stewart, G. 1997. Supply-chain operations reference model (SCOR): The first cross-industry framework for integrated supply-chain management. Logistics Information Management., 10(2), pp. 62-67. 
[65] Lambert, D. M. and Enz, M. G. 2017. Issues in supply chain management: Progress and potential. Industrial Marketing Management, 62, pp. 1-16.

[66] Mentzer, J. T., Keebler, J. S., Nix, N. W., Smith, C. D. and Zacharia, Z. G. 2001. Defining supply chain management. Journal of Business Logistics, 22(2), pp. 1-25. 


\section{APPENDIX 1: CLASSIFICATION OF STUDIES BY TYPE OF PUBLICATION}

It can be observed that many studies are derived from journals and conference papers. Only two reports emerged from the literature, searched through a systematic literature review approach. This is shown in Table A.

Table A: Classification of studies in the systematic literature review

\begin{tabular}{|c|c|}
\hline Name of Journal & Number \\
\hline Journal of Operations Management & 5 \\
\hline Industrial Management and Data Systems & 3 \\
\hline Industrial Marketing Management & 3 \\
\hline The International Journal of Logistics Management & 3 \\
\hline Industrial Management & 2 \\
\hline International Journal of Physical Distribution \& Logistics Management & 2 \\
\hline International Journal of Production Economics & 2 \\
\hline Production Planning and Control & 2 \\
\hline Information Strategy: The Executive Journal & 1 \\
\hline Information Technology and Management & 1 \\
\hline International Journal in Supply Chain Management & 1 \\
\hline Journal of Computers and Electronics in Agriculture & 1 \\
\hline Journal of Fashion Marketing and Management & 1 \\
\hline Journal of Industrial and Production Engineering & 1 \\
\hline Journal of Marketing Channels & 1 \\
\hline Journal of the Academy of Marketing Science & 1 \\
\hline Manufacturing \& Service Operations Management & 1 \\
\hline South African Journal of Business Management & 1 \\
\hline The Journal of Business Forecasting & 1 \\
\hline Total number of journals & 34 \\
\hline IFIP Advances in Information and Communication Technology Conference & 2 \\
\hline Proceedings of International Trade and Logistics, Corporate Strategies and Global Economy & 1 \\
\hline 17th International Logistics Congress, Thessaloniki & 1 \\
\hline 16th International Conference on Industrial Engineering and Engineering Management & 1 \\
\hline Proceedings - 2nd International Workshop on Engineering Management for Applied Technology, EMAT & 1 \\
\hline IEEE Intelligent Transportation Systems - Proceedings & 1 \\
\hline Conference proceedings & 7 \\
\hline The Boston Consulting Group & 1 \\
\hline American Institute of Chemical Engineers & 1 \\
\hline Reports & 2 \\
\hline Total studies in systematic review & 43 \\
\hline
\end{tabular}

